\title{
Inheriting the Homeland? Intergenerational Transmission of Cross-Border Ties in Migrant Families ${ }^{1}$
}

\author{
Thomas Soehl and Roger Waldinger \\ University of California, Los Angeles
}

\begin{abstract}
Theories of migrant transnationalism emphasize the enduring imprint of the premigration connections that the newcomers bring with them. But how do the children of migrants raised in the parents' adopted country develop ties to the parental home country? Using a structural equation model and data from a recent survey of adult immigrant offspring in Los Angeles, this article shows that secondgeneration cross-border activities are strongly affected by earlier experiences of and exposure to home country influences. Socialization in the parental household is powerful, transmitting distinct home country competencies, loyalties, and ties, but not a coherent package of transnationalism. Our analysis of five measures of cross-border activities and loyalties among the grown children of migrants shows that transmission is specific to the social logic underlying the connection: activities rooted in family relationships such as remitting are transmitted differently than emotional attachments to the parents' home country.
\end{abstract}

\section{INTRODUCTION}

International migration recurrently yields cross-border ties since connections are often part and parcel of the familial survival strategies that propel migration in the first place. Connections then produce greater connectedness as the density of cross-state ties creates a supportive "transnational so-

${ }^{1}$ This research was supported by grants from the Russell Sage (no. 88-11-01) and National Science (SES-0751944) Foundations. Support for Thomas Soehl was provided by the University of California, Los Angeles, Graduate Division, a predoctoral advanced quantita- 
cial field" (Fouron and Glick-Schiller 2002; Levitt and Glick-Schiller 2004). Implying that migrants engaged in intense, ongoing cross-border connections will be the neighbors, friends, or acquaintances of migrants engaged in more occasional or even evanescent contacts, this concept points to the ways in which high concentrations of migrants with varying degrees of home country connectedness can promote ties for any and all who might be interested.

These accounts explain both why migration generates subsequent crossborder ties and why those linkages might persist, emphasizing the enduring imprint of the premigration connections that the newcomers bring with them. For that very reason they do less well in illuminating why and how cross-state connections may be maintained by the next generation. While those born in the country of origin import and then retain homeland ties, those same connections need to be transmitted to those born in the country of destination. Generally, as other researchers have shown, the passage from the first to the second generation leads to a weakening, and sometimes even a disappearance, of homeland connections. Among some immigrant offspring, however, those ties do persist, in some cases with considerable intensity. Explaining these variations in the transmission of cross-border connections and accounting for differences in the ways in which the transmission process may vary by type of cross-border activity remain open, unexplored questions.

These are the issues to which this article attends. In the remainder of the article, we argue that the parental household provides the key conduit for the transmission of second-generation home country attachments, via both homeland-oriented activities and homeland practices that immigrant parents retain. Moreover, these parental activities do not entail a coherent package of homeland-oriented interests and activities but rather distinct competencies, loyalties, and ties with distinct mechanisms of social integration (Faist 2000), whose effects in turn will vary across the very distinct types of potential cross-border connections.

In the following sections, we draw on existing research on secondgeneration transnationalism and also on theories of social learning and political socialization. We use this literature to develop a set of predictions about how different types of parental cross-border engagements as well as parental incorporation into the host society will shape second-generation transnational ties. We then use data from the Immigration and International Mobility in Metropolitan Los Angeles Survey (IIMMLA) to assess

tive methodology training grant (no. R305B80016) awarded to the University of California, Los Angeles, by the Institute of Education Sciences of the U.S. Department of Education, and the ZEIT-Stiftung Ebelin und Gerd Bucerius. Responsibility for conclusions reported in this article is that of the authors alone. Direct correspondence to Roger Waldinger, Department of Sociology, University of California, Los Angeles, Haines Hall 264, Los Angeles, California 90095. E-mail: waldinge@soc.ucla.edu 
these hypotheses. Collected in 2003 and 2004, the IIMMLA interviewed approximately 4,500 young adults of ages 20-39 in the Los Angeles metropolitan area (Rumbaut et al. 2004). These data, involving quota samples for a variety of Latin American- and Asian-origin second- and 1.5-generation groups, are well suited for the purposes at hand. As a survey of the premier U.S. immigrant metropolis, and one with a built-up welter of connections to the various global sources of today's immigrant population, IIMMLA was conducted in precisely that location most likely to provide the type of transnational social field facilitating cross-border connections. The survey is also unique in that it contains a wealth of information both about respondents' home country connections at the time of the survey and about the home country ties maintained by parents when the respondents were still children at home. The survey's extensive battery of sociodemographic and migration questions provide further resources for exploring the transmission of homeland ties from one generation to the next.

\section{FROM "HOW MUCH?" TO "HOW?"}

Although a relatively new topic, the study of second-generation homeland ties is generating a rapidly growing literature. Levitt and Waters' pioneering collection (2002) of U.S.-based research, the first major entry into the question, provided a mixed assessment, with most authors finding "some evidence that the children of immigrants are transnational actors" (p. 4) but also numerous indicators of detachment. The papers also showed that second-generation home country connections vary in type and level of intensity, with clear intergroup and life-cycle differences. Reviewing the transnationalism and assimilation literatures, Morawska found that "significant numbers" of immigrant offspring "engage in different forms of transnationalism"; still, she concluded that assimilation is "much more central" to the second than to the first generation, with the former generally unlikely to maintain "active transnational involvements" (Morawska 2003, p. 154).

A number of recent sources provide support for that generalization. Kasinitz et al.'s study of second-generation New Yorkers found that "most groups have low levels of transnationalism, and transnational activities do not always reinforce ties to the homeland . . . sustained transnationalism is therefore unlikely to persist into later generations" (2008, p. 264). Itzigsohn's (2009) book on first- and second-generation Dominicans, a population among whom home country connectedness takes a particularly strong form, demonstrates that home country loyalties and attachments can get passed down from the first generation to the second generation, albeit in very different forms. While a core group of Dominican immigrant offspring regularly engages in transnational practices, it is nonetheless "smaller and less intensively engaged in transnational activities than the first generation" 
(p. 154). Analysis of the 2006 Latino National Survey $(N=8,634)$ shows that, across a variety of indicators, cross-border connectivity dramatically declines from the first to the second generation and then declines further with subsequent generations (Fraga et al. 2010, 140-42). For example, while more than half of Latino immigrants report being in contact with friends and family back home once a week or more often, a little over $30 \%$ of the second generation and only $15 \%$ of the third generation have weekly contact. Similarly, only $10 \%$ of first-generation respondents report having ceased all contact with relatives or friends, as opposed to $20 \%$ of secondgeneration and more than $50 \%$ of the third and later generation respondents. While cross-border political interest and organizational involvement show smaller intergenerational declines, rates for the first generation are already very low.

This decline in cross-border ties may reflect the difficulties entailed in maintaining satisfying homeland connections. While Smith (2006) highlights the many and enduring ties linking second-generation Mexican New Yorkers with their hometown (dubbed Ticuani), he also demonstrates the fissures dividing the New Yorkers and the Ticuanenses. The former possess what the latter lack: "designer sneakers, fashionable clothes, and gold chains, present[ing] an image of modernity and power" (p. 247), not to speak of something of which many of the stay-at-homes can only dream, namely, "the power to leave Ticuani to go north" (p. 248). Not surprisingly, returning second-generation youth find that "their standing in Ticuani is contested" (p. 262). Other studies sound similar themes. The children of former Turkish guestworkers - the functional equivalents of Smith's Mexican New Yorkers - are often viewed as alien by Turks who stayed behind (Lucassen 2006). At the other end of the immigrant class spectrum, the second-generation Chinese Americans and Korean Americans studied by Kibria found that homeland trips made them "painfully aware of how suspect they were as true Chinese or Koreans" (2002, p. 50). Much evidence also suggests that birth and upbringing in a new country generate significant cleavages between immigrant descendants and the people and places from which they stem. Thus, Smith notes that "settlement and transnationalization work at cross-purposes," with second-generation Mexican New Yorkers expecting their futures to unfold in New York as "the demands of their assimilated lives in New York" (2006, p. 204) weaken cross-border engagements. Purkayastha (2005, p. 14), examining second-generation South Asians, contends that destination country structures "will be more relevant to the everyday lives of the second generation."

These fissures notwithstanding, homeland connections do persist among some immigrant offspring. Furthermore, a certain portion of this population maintains intense, continuing cross-border engagements. Hence, a preoccupation with the average experience of diminishing cross-border con- 
nectivity may be misleading. Moreover, averages can conceal significant differences across groups and individuals. While Kasinitz et al. (2008) show that only some immigrant offspring, regardless of group, keep up home country connections, they also highlight the extent of cross-group variation, with levels of remitting and visiting among Dominicans far higher than those of Russian Jews or Chinese. Louie's (2006) comparative case study of Dominicans and Chinese puts the contrasts in still sharper relief, while underscoring the factors that might strengthen homeland contacts in one context and weaken them in the other. Generally lacking Chinese language capacity, making few trips back to China, and then finding the experience difficult due to a communication gap, Louie's Chinese respondents had weak transnational attachments and orientations. By contrast, Spanish retention was higher among Dominicans, who made more frequent visits, which in turn proved more satisfying since the face-to-face interpersonal connection with stay-at-homes was easier to sustain.

Yet, the literature provides no theory about what would lead the children of migrants born "here" to connect with the parental home country "there." Nor does it provide much explanation for within-group, cross-individual differences in the nature and extent of those ties.

Some accounts, however, are suggestive. Studying Chinese and Korean immigrant offspring, Kibria found that exposure to the economic dynamism of their parental home countries bolstered a sense of national pride (Kibria 2002, p. 167), demonstrating the potential value of "ethnic identity capital" (p. 201). Other research, however, suggests that engagement with the parental home country may instead be linked to negative experiences in the local context. Thus, Espiritu found that those Filipino immigrant offspring actively engaged in ethnic politics and mobilization against discriminatory politicies often felt a strong emotional connection to the parental home country (Espiritu 2003, p. 204).

By contrast, Smith's in-depth ethnography of Mexican immigrant offspring underlines the importance of the parental household. In this case, homeland attachment stemmed from in-person, physical engagement with the parents' hometown during childhood and adolescence. As these experiences often entailed long summertime sojourns of an intense and enjoyable kind, thereby contrasting with the more confined environment encountered back in New York, they generated deep feelings of connectedness. While Smith's study focuses on the connected, the logic of the argument suggests that immigrant offspring lacking the early experience of travel-perhaps because of lack of resources, perhaps because parental lack of legal status precludes return visits - will be unlikely to develop a similarly keen, lasting attachment to the place from which their parents came.

Thus, while the existing scholarship has begun to shift from the question of "how much" to "how," it only hints at the sources of variation in second- 
generation homeland attachments. In a sense, the most important implication is never explicitly stated: namely, that connections and connectedness are imparted from parents to children, whether by example (e.g., sending remittances or participating in ethnic associations), by investment (traveling with children to the place of origin), or by imparting the tools (language, familiarity with home country customs) that would allow offspring to sustain home country ties on their own as adults. Going deeper requires a more focused effort to understand the pathways by which these cross-border connections are transmitted from one generation to the next and the ways in which variations in parental home country connections affect those same connections among their adult children born or raised in the United States. It is to this task of specifying hypotheses to which we now attend.

\section{Hypotheses}

The concept of the transnational social field suggests that parental home country influences are not only widespread but also readily available for the second generation. But what concrete social influences and institutions lead the second generation to engage in cross-border activity? How do the children of migrants born "here" (in the United States) develop ties and loyalties to the people and places "there," as well as the skills needed to maintain those linkages? These questions are especially relevant since the second generation, born and/or growing up in the host country, is exposed to myriad socializing forces that will orient them toward "here"- the place where they reside - rather than "there" - the place from which they or their parents came. Hence, identifying the source that might nourish homeland connections is crucial to understanding why second-generation cross-border ties persist.

We contend that one central source of second-generation connections across borders stems from foreign-born parents and the behavioral patterns that the latter adopt both within the household and outside it. First, social learning within immigrant households provides the mechanisms by which cross-border activities and ties get constructed. Second, differences in retention of homeland traits or practices shape both the competencies needed to keep up homeland ties and the affective dispositions that motivate those engagements. Third, parental integration into the host society has potentially contradictory impacts, providing resources for continued home country engagement but possibly also attenuating those ties. Last, those lessons do not take a common, all-purpose form, but rather vary, depending on the specific choices that immigrant parents make, regarding the range of home country connections; consequently, any homeland-oriented activity or practice in which parents engage transmits competencies and preferences best suited to that specific cross-border engagement and not necessarily others. 
Social learning. - In emphasizing the intergenerational transmission of home country attachments, we draw on the large literatures on political socialization and social learning, which have long emphasized the ways in which experiences within the parental household during childhood and youth affect civic and political values, attachments, and activities undergone later in adulthood (Hyman 1959; Jennings and Niemi 1968; for social learning theory more generally, see Bandura 1977). ${ }^{2}$ These approaches have experienced a recent revival in explaining the civic socialization of children and young adults (Niemi and Hepburn 1995; Jennings, Stokers, and Bowers 2002) and have also been applied to the study of migrant political engagement (Bloemraad and Trost 2008) and socialization (Wong and Tseng 2008).

These perspectives generally take citizenship for granted, applying social learning processes to explain civic engagement and political loyalties in the country of birth. Indeed, as Sapiro notes, "political socialization research has focused primarily on the development of citizenship in the United States" (2004, p. 6), assuming away the possibility of nested nationalities, memberships, or citizenships. While nested affiliations of these sorts are precisely the phenomena of interest here, the underlying issue entails the same question as that posed by the students of political socialization, transformed to ask how parents' attachments linked to their country of birth get transmitted to children raised in the parents' country of adoption.

Homeland ties are likely to be an integral part of immigrant households. Parents' engagements with the homeland and the people still living there are likely to influence their children as they serve as examples within the family context, providing a critical pathway by which the native-born second generation acquires the competencies and loyalties that both motivate and enable homeland engagement. For some types of cross-border ties, such as political interest in the home country, predictions regarding the development of emotional attachments or engagement in transnational organizations from the (narrower) political socialization literature can be extended straightforwardly. Research on political transmission has shown that children growing up in highly political families will be more likely to be politically engaged as adults themselves and to have more stable political orientations (Jennings and Niemi 1974; Verba, Schlozman, and Brady 1995; Jennings et al. 2001). We expect that children of migrants who are ac-

\footnotetext{
${ }^{2}$ There was considerable discussion in the political socialization research concerning whether the family or schools were the more important socializing agents. Hess and Torney-Purta (1965) argued that families were "only one of several socializing agents and institutions," while the "public school is the most important and effective instrument of political socialization in the United States" (quoted in Jennings and Niemi 1968). In our context, the public school system would be an agent of socialization toward the nationally bounded polity (Gellner 1983; Anderson 2006).
} 
tively involved in home country affairs are more likely to be engaged in or interested in homeland politics during adulthood; our data, unfortunately, do not allow us to explore this possibility.

However, the broader set of predictions of the social learning and social cognitive literature are applicable for other types of connections, such as home country visits or the sending of remittances, for which the data set supplies information. According to this set of theories, observational learning through actual and symbolic modeling is a key feature in the acquisition of competencies, attitudes, values, and loyalties (Bandura 1986). The process of absorbing social practices and customs from models that display them is central to the reproduction of cultural patterns over generations (Bandura 2002, p. 273). An example of just how parental models might be absorbed in the cross-border context comes from a recent ethnographic study of migrants in Finland: "Although phoning and staying in touch were mostly parental practices," and children often just exchanged a few words or just listened, the children were nonetheless "incorporated in the transnational communication patterns and knew who called who, how often, and how much it cost" (Haikkola 2011, p. 1208). Thus, since parents provide the key models for children, we expect that their modeling of crossborder engagement will significantly predict transnational ties in the second generation.

Hypothesis 1.-Building on the implications of social learning theory, we expect that parental influence matters for the cross-border activities of the second generation. Parents who are involved in cross-border activities model homeland engagement and pass on the skills and dispositions that their children will need in order to maintain cross-border activities in adulthood.

Home country practices - language.-Differences in retention of homeland traits or practices will yield later differences in children's homeland attachments. Of these, the most important is language, shaping social boundaries in its role as a means of communication. While "anything can become symbolic of ethnicity," as Fishman argues (1989, p. 32), language, as the prime symbol system, is particularly likely to play that role and therefore "is often a focus of an 'us-them' concept" (Fasold 1984, p. 240). Communication and culture are inextricably intertwined since language is both a symbol and a tool of membership. As ethnic identity is linked to the very words used to demarcate intergroup boundaries (e.g., goyim; gabacho), language is in turn part and parcel of those boundaries themselves (Giles and Coupland 1991). Consequently, for minorities of foreign background, language retention and ethnic identity are strongly interconnected (Alba 1990). Last, as the means of communication, language can define the boundaries of membership, excluding all those who lack the ability to speak in a common tongue. 
In the host society, therefore, language shift is at once an indicator and a mechanism of the blurring of ethnic boundaries. In the model developed by Fishman, the first generation retains the mother tongue for most purposes, using the dominant tongue only in those domains where its use is required. While the first generation's children may be exposed to the mother tongue at home, the dominant tongue rules in all other domains - the neighborhood, schools, and work - and therefore prevails, relegating the mother tongue to the parental home, where even there it is used with diminishing frequency. Although a variety of factors can modify this process - most notably, the increased density of mother tongue speakers associated with high levels of ongoing international migration, as well as proximity to the country of origin - current research (Alba and Nee 2003; Bean and Stevens 2003; Rumbaut, Massey, and Bean 2006; Lopez and Estrada 2007) indicates that the basic pattern identified by Fishman remains in place.

The conventional literature focuses on the host society and is concerned with the linguistic boundaries between groups of foreign and native origin living in the same territory. But the question of second-generation engagement in the homeland takes a different form: bringing in the cross-territorial dimension, it asks whether immigrant offspring, though raised on hostsociety (hence, from the homeland standpoint, foreign) soil, can function in the parents' home society with the competencies approximating those of natives. Thus, while language shift might reduce host-society social boundaries between foreign-origin minorities and native-born majorities, it may also increase the cross-border social boundary between stay-at-homes in the country of emigration and foreign-born offspring raised in the country of immigration. As noted in the literature review above, numerous empirical studies have shown that an inability to effectively communicate in the homeland tongue weakens satisfying second-generation cross-border engagement. Given these tight interconnections, loss of mother tongue facility is likely to weaken both the motivation to claim a cross-border identity and the capacity to ensure that any such claim is validated by the hometown or homeland community.

Hypothesis 2.-For immigrant offspring, parental linguistic practices during childhood yield dispositions and competencies affecting the potential for later homeland engagement in adulthood.

Parental national integration. - The migrant parents of the second generation engage in cross-border activities, albeit to varying degrees. However, they also become integrated into the national societies of the destination countries on which they have converged (Banton 2001). They may learn the host country language, which as a tool for communication fosters interaction with the native-born population and as symbol signals membership. Their everyday lives lead to engagement with institutions of the host state, whether via the schools that their children attend, unions or civic organiza- 
tions in which they participate (Terriquez 2011), or government services that they access. Most importantly, immigrants may acquire citizenship, joining the political community, an action that may increase access to resources and stabilize their standing but also yield changes in identity and affiliation.

According to many scholars, national integration is fully compatible with, and may possibly even promote, continuing home country engagement. As suggested by research indicating that naturalized citizens are more, not less, involved in cross-border engagements than their noncitizen counterparts (Guarnizo, Portes, and Haller 2003), political incorporation, via the acquisition of citizenship, may provide the protection needed for the type of open, forthright, and public expression of homeland loyalties especially likely to influence the attachments and orientations of immigrant offspring. Moreover, since hostland citizenship also provides the unhindered right to cross borders and travel to home communities, it is also likely to increase the potential for in-person homeland contacts.

Parental integration may also positively influence second-generation socioeconomic mobility, thereby yielding further indirect effects on crossborder connectedness. As recently shown by Bean et al. (2011), also analyzing IIMMLA, membership acquisition by Mexican immigrant parents increases educational attainment among their children. In turn, higher levels of schooling among immigrant offspring could be the source of the material resources needed for travel or remittance sending or the cognitive resources that would facilitate engagement in home country politics.

However, parental integration also has the potential to dampen the transmission of the skills and preferences on which cross-border engagement depends. The symbolic importance of citizenship acquisition may generate a deeper sense of receiving society membership; by opening the door to participation in the host country polity, political incorporation may also encourage political engagement-further drawing the migrant into host country social networks. Following the logic of assimilation theory (Alba and Nee 2003), which forecasts that assimilation will reduce proximity to and dependence on coethnics, parental national integration and second-generation social mobility might lead to a distancing from the ethnic infrastructure supporting the transnational social field.

Hyротнеsis 3.-Parental host society incorporation will have variable effects. On the one hand, it may pull families away from transnational social fields, thus limiting the transfer of connections to the home country. On the other hand, host society incorporation, by increasing material and cognitive resources, may foster second-generation homeland engagement.

Parental choices and offspring response.-Cross-border activities take myriad forms, whether involving communication, travel, the sending of remittances, political engagement, profit-making ventures, or philanthropy, 
to name just a few of the most important types. These different activities are qualitatively distinct, as emphasized by Faist (2000), who points out that some cross-border activities and exchanges are particularistic, entailing connections between specific families or kinship groups, whereas others work at a higher level of aggregation, involving identification with a trans-border community. In Faist's view, moreover, each type of cross-border tie possesses its own social logic, based on a distinct "mechanism of integration" (p. 191), set of resources, and norms, all of which undergird connectivity.

Many scholars have also underscored the quantitative differences in the range and consistency of cross-border activities. High-intensity, across-theboard activities involving physical movement that characterize the "transmigrants" (Portes, Guarnizo, and Landolt 1999) appear to be relatively rare (Portes, Haller, and Guarnizo 2002; Guarnizo et al. 2003; Waldinger 2008). More commonly, migrants engage more selectively, as indicated by the various efforts to identify the multifarious, often intermittent activities that link migrants and homelands. Thus, Itzigsohn et al. (2000) write of "broad transnationality" (p. 323), a concept they coin to describe how migrants' involvement with homelands could be occasional, lacking in institutionalization, and only sporadically involving physical movement (p. 323). Similarly, Levitt (2001) pointed out that, in addition to the transmigrants engaged in "comprehensive transnational practices," others were involved in practices that were "more selective in scope" (pp. 198-99).

Building on this scholarship, and focusing on Faist's particularistic activities linking egocentric networks of migrants and stay-at-homes, Soehl and Waldinger's (2010) study of Latino immigrants in the United States showed that the great majority maintained some type of cross-border connection but that remitting, travel, and regular cross-border communication rarely came together in a single package. Instead, migrants were picking and choosing among the relevant possibilities, generally tending not to combine the more costly activities of travel and remittance sending. Furthermore, each option was associated with a distinct set of specific migrant characteristics.

While Soehl and Waldinger conclude that "the typical migrant is the connected" (2010, p. 1507), other research (Waldinger, Soehl, and Lim 2000) shows that fewer engage in those cross-border activities that Faist sees as linked to a collective identity than choose to keep up ties to particular others at home. To be sure, almost every migration includes its cadre of migrants oriented toward concerted action, whether targeted at a hometown or a homeland. Yet involvement is relatively rare and often confined to a stratum of well-established, better-off migrants who have kept up homeland ties. More immigrants pay some attention to homeland politics, which, if talked about with children, may kindle their interest (Wong and Tseng 2008). Yet, in the absence of mobilization by homeland-oriented groups and 
with limited avenues for participation, interest flags, even among those engaged in ongoing interactions with relatives at home.

As argued above, parents typically choose among a range of activities that entail or facilitate cross-border involvement; in turn, each choice yields a likely effect on later second-generation cross-border engagement. For example, sending remittances demands a sense of loyalty and responsibility to a family member not necessary for an emotional attachment to the parental home country. Likewise, feelings of connection to a parental homeland may not entail the skills or interest needed to participate in a homeland-oriented organization. Similarly, one can display an interest in homeland politics without possessing the linguistic fluency needed for easy interaction in the homeland context.

Нyротнеsis 4.-Hence, in selectively choosing among a broad range of cross-border engagements, immigrant parents do not transmit "transnationalism," whether core, expanded, broad, comprehensive, or selective. Rather, parents convey particular dispositions or skills bound up with the specific cross-border activities in which they engage. Consequently, arms-length involvement — such as those entailed in remittances - yield different effects than those involving in-person, face-to-face interactions, and egocentric engagements bear little relationship to involvements linked to some homeland collective identity.

Focusing more specifically, we expect that parental remittance sending will have a behavioral modeling effect, as described above. While the act of parental remitting and associated conversation in the parental household may also be part of a learning process that transfers filial obligations to the second generation, remittance sending is representative of what Faist (2000) labeled "kinship ties," and therefore we do not expect that, controlling for other pathways, the set of loyalties transferred will extend to other realms, such as emotional connections to the parental home, political interest, or increased likelihood of visiting.

Although costly, sending remittances is relatively simple. Visits are costlier; as the ethnographic evidence shows, they are also complex to manage, as they have the potential to "emphasize difference as much as generate shared understandings" (Mason 2004, p. 427). Hence, while parents making return visits may send children a signal about the importance of loyalty to the people and places left behind, more may be needed if the children are to sustain those visits during adulthood. By contrast, childhood visits undertaken with parents are likely to impart both the competencies needed to fit in during a visit and the skills and dispositions required for managing and negotiating long distance that only occasionally involve copresence. Moreover, if the experience during childhood is positive (see Louie 2006), the relationships generated and the memories attached to them may fuel further cross-border attachments in adulthood (Haikkola 2011, p. 1210). 
Similarly, we hypothesize that the presence of parental language in the household will have two kinds of effects. As argued above, facility in the parental native language is a competency key to maintaining numerous crossborder activities, most notably those in which language ability is integral to the experience, such as visiting. As presence in the household when growing up is probably the central transmission mechanism for parental language fluency, we expect that those respondents who grew up in households with a strong home country language presence will be more likely to visit these places as adults, net of other factors.

But language is not simply a tool for communication; it also has powerful emotional connotations. Home, as Schuetz noted decades ago, is where shared meanings and understandings can be taken for granted, which is why he understood " 'to feel at home' [as] an expression of the highest degree of familiarity and intimacy (1944, p. 370)." Precisely for that reason, as noted far more recently by Brubaker and colleagues, "the experience of speaking 'one's own' language is often associated with a feeling of phenomenological comfort, a sense of being at home in the world" (2006, p. 254). Following these authors, we expect that the presence of the parental home country language will predict emotional attachments such as the likelihood of feeling at home in the country of origin. In contrast, we expect that, other things being equal, language should matter little, if at all, for homeland-oriented activities occurring in the host land for which linguistic facility is not required, such as political interest in homeland matters or membership in parental homeland-oriented organizations.

Data

This article analyzes data from the Immigration and Intergenerational Mobility in Metropolitan Los Angeles Survey (IIMMLA) to assess these hypotheses. Collected in 2003 and 2004, the IIMMLA interviewed a total of 3,440 children of immigrants in the Los Angeles metropolitan area. IIMMLA is one of a small number of data sets specifically designed to understand the experiences of today's second generation. While the other major data sets - the Children of Immigrants Longitudinal Survey (CILS) and the recently released Immigrant Second Generation in Metropolitan New York (ISGMNY) - also contain information relevant to understanding cross-border connections, IIMMLA is superior in a number of ways. Whereas IIMMLA sampled for persons ages 20-39, ISGMNY sampled for a younger population and CILS for one much more so (and one with very little variance in age). As IIMMLA respondents are therefore more likely to be living on their own, their cross-border engagements are less likely to reflect direct parental involvement or preference than would be true for the 
younger CILS or ISGMNY respondents (Jones-Correa 2002, p. 234), who were often still living in their parents' households.

Moreover, only IIMMLA contains information relevant to our concern with intergenerational transmission. Data about home country connections were only collected in the third wave of CILS, which pertained to respondents at that point in time and no other. While ISGMNY asked one question about parents' cross-border activities, the query asked respondents about activities at the time of the interview, as opposed to the temporal focus on activities at the time of respondents' childhood, which was emphasized by IIMMLA. In addition, IIMMLA includes a wider battery of relevant items, as well as information regarding parents' legal status at the time of the interview, data not found in either of the two other surveys. While IIMMLA is not ideal in either question wording or the mix of questions, as to be noted below, it nonetheless remains the richest, most appropriate resource available.

Although all IIMMLA respondents are age 20 or over, and therefore can be considered adults, half of these respondents are still living with their parents and thus will be excluded from the analysis. This procedure reflects our interest in understanding how and to what extent parents' activities and traits experienced by their offspring when children yield cross-border connections for those same offspring when adults. By contrast, most previous research on second-generation cross-border activity does not distinguish between those who still live with their parents and those who are independent adults (Jones-Correa 2002). ${ }^{3}$

In a first analysis, we aggregate all respondents, regardless of place of origin. This gives us a representative view of the processes that facilitate crossborder connectedness in the second generation in Los Angeles. However, these results may differ across groups since the cross-border relations of migrants are critically shaped by the circumstances of migration and the context of reception. To address this concern, in a next step, we break out respondents by parents' region of origin, looking at three broad regional groupings separately. The IIMMLA survey only provides a large enough sample for one national origin group: Mexicans - the largest immigrant population in the United States and one with a particular concentration in the Los Angeles area. We group other respondents by region of origin, but

\footnotetext{
${ }^{3}$ We note that the timing of data collection as well as the age distribution of the sample entails an important temporal implication: the respondents were born between 1963 and 1983; all entered by the year 2000 and most well before then. Among the Mexican and Central American samples, a significant minority of the respondents either entered as undocumented immigrants or were the children of parents who entered in an undocumented status. But as the great majority were living in the United States as of the 1982 cut-off date for the 1986 amnesty act, most of the former undocumented parents and children had obtained either legal permanent residency or citizenship as of the time of the survey.
} 
only those with parents from Asian countries provide a large enough sample to allow stable estimates. ${ }^{4}$

\section{ANALYSIS AND VARIABLES}

To assess the hypotheses specified above, we develop a structural model, summarized in figure 1, which relates parents' characteristics to transnationalism in the second generation. ${ }^{5}$ The left side displays the variables pertaining to the immigrant generation at the time of the respondents' childhood. The right side displays characteristics of the U.S.-born or -raised children interviewed by IIMMLA, as well as five variables indicating homeland-oriented activity or attachment: visits to the parental home country, sending of remittances, membership in organizations related to the parental home country, interest in politics of the parental home country, and sense of feeling at home in the parental home country.

To model these variables, we chose a structural modeling approach, as this gives us two advantages over a standard regression. First, it allows us to create a single variable to represent the concept of parental incorporation into the host society. Second, the structural model allows us to trace the paths of independent variables as they affect the transnational engagement of the second generation directly as well as indirectly. As outlined above, parents' incorporation may yield an effect on children's cross-border activity via its impact on parental involvement in cross-border activity or on second-generation resources that might influence cross-border ties, such as education.

\section{Parents' Cross-Border Activities and Retention of Homeland Traits}

Our key independent variables indicate to what extent the second generation was exposed to cross-border activities and homeland traits while growing up in their parents' home. The IIMMLA provides information on the sending of remittances and visits to the home country and also on the

\footnotetext{
${ }^{4}$ The IIMMLA survey employed sampling quotas for second-generation national origin categories relative to the population of the Los Angeles area. Therefore, it underrepresents some groups (e.g., Mexicans) and overrepresents others (e.g., Chinese). To adjust for this disparity, we used 2000 U.S. Census data on the number of native born in each national origin category in the Los Angeles metropolitan region to weight the sample, and we used the weights when analyzing all respondents, regardless of place of origin, but not when disaggregating by place of origin.

${ }^{5}$ For clarity, fig. 1 shows only one of the second-generation transnational activities connected to the other variables in the model - in the estimation, we model all five simultaneously.
} 


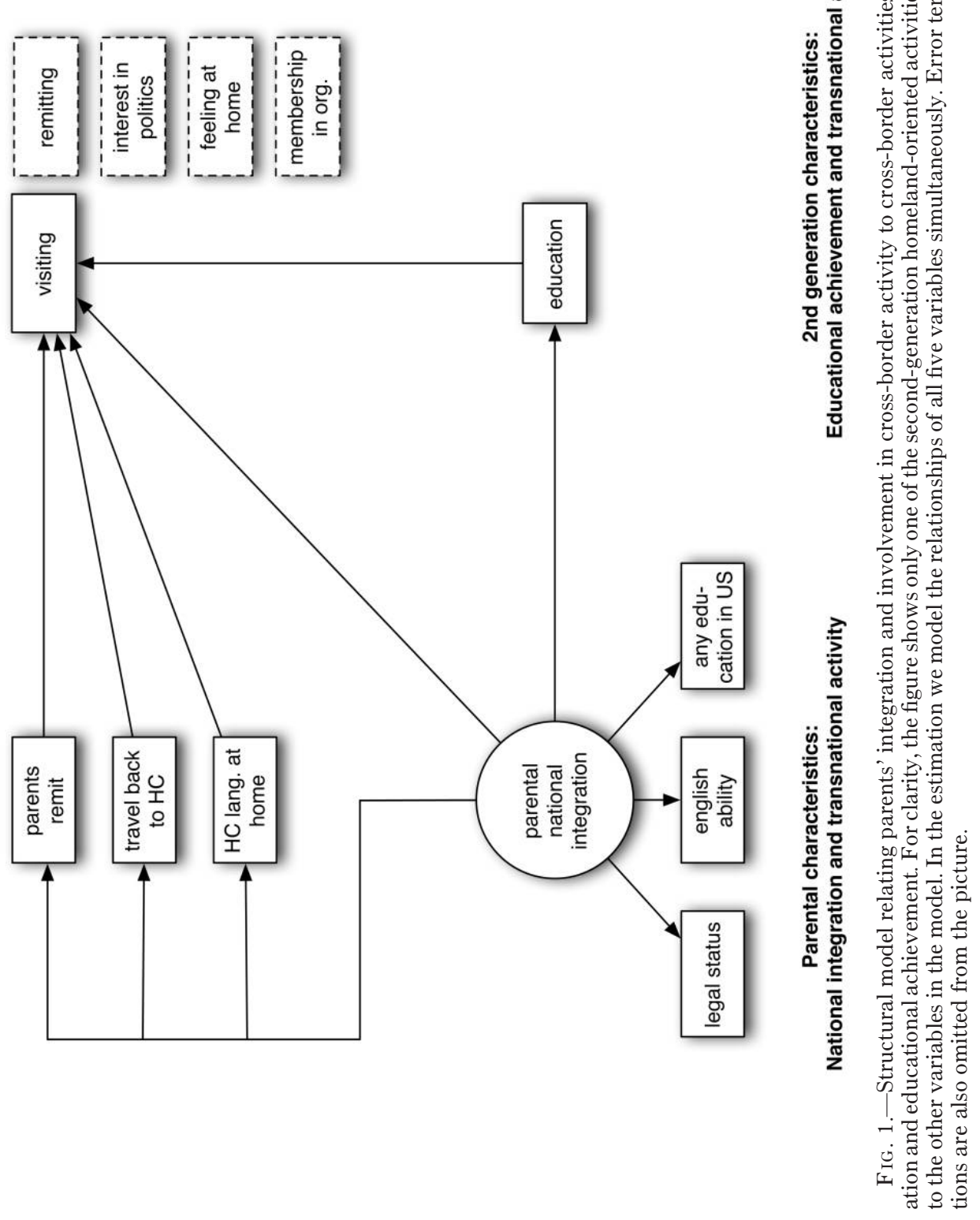


prevalence of the home country language in the household. Summary statistics and detailed coding for these variables can be found in the appendix.

Remitting.- Respondents were asked whether their parents sent money to anyone in either the father's or the mother's country of origin. Almost two-thirds of the parents did so. Unfortunately, additional information that could capture the varied nature of the phenomenon is not available. Data from other immigrant surveys, however, do suggest that the large majority of those who ever remitted did so on a fairly regular basis, sending money either monthly or several times a year. For example, in the 2006 Latino National Survey (Fraga et al. 2006), of those migrants who did remit, 85\% did so at least every couple of months and less than $5 \%$ of those who remitted did so less than yearly. In contrast, $35 \%$ of migrants never sent money back home.

Return to the home country with parents.-Respondents were asked whether any parent ever returned to their home country for 6 months or more. In a follow-up question, respondents were asked whether they joined their parents on this trip. We combined these two variables into a single indicator variable taking the value 1 if a parent went back and the respondent joined the parent on the return trip and 0 in all other cases. ${ }^{6}$ About $11 \%$ of our respondents made such a trip when growing up. This variable fails to capture the more mundane and also more ubiquitous short-term visits to the home country that may well shape home country attachments in the second generation. On the other hand, as we have argued above, this question does pick up the time involved, the childhood experience of return, and the company of a parent, all of which are likely to increase the long-term impact of these particular childhood experiences.

Summing up, the parents of the IIMMLA respondents resemble Soehl and Waldinger's "connected," as most retain some cross-border connections but also choose among homeland-oriented activities. Thus, the majority either returned to the home country for six months or sent home remittances. While only one-third did neither, an even smaller group, $8 \%$, did both.

Prevalence of home country language in the household.-The survey asked respondents about the use of the parental language in the household when growing up. This variable is coded in four ordered levels: (1) if English was spoken at home exclusively, (2) if mostly English was spoken at home, (3) if the home country language and English were spoken about the same, and (4) if mostly the home country language was used at home. During childhood, the parental home country language was dominant in about

\footnotetext{
${ }^{6}$ In a separate analysis, not shown here, we also estimated the effect of parental return when the respondent did not join, and we found no effects, with the exception of interest in politics. This result, we argue, strengthens our claim that, in addition to modeling, the concrete exposure of immigrant offspring during home visits plays a crucial role in the transmission of cross-border connections.
} 
half of respondents' households; fewer than one in 10 grew up in a family where English was the only language spoken. However, we also note significant national origin differences, with Asians much less likely to be exposed to their parental mother tongue than Mexicans. ${ }^{7}$

Parental integration and educational achievement of the second generation.-Since there is no single way to measure parental integration into the national society of the destination country, we construct a latent variable using three observed variables as indicators: parents' legal status, their English ability, and whether they received any education in the United States. These variables are indicators of national integration, as they bear on the membership status, institutional involvements, and behavioral changes entailed in the process by which immigrants become part of the national society in which they have settled. Our latent variable relates the common variation of the three indicators to the other variables in our model.

Looking at the individual components of this measure, we notice that a relatively small portion (about 6\%) of respondents report growing up without a guardian with legal status. About one-quarter of respondents grew up in households where no parent could speak English well, but in almost half of households, both parents did. Most parents (about 80\%) did not obtain any further education in the United States. Comparing between Mexicans and parents from Asian countries, we see that Asian parents score somewhat higher on all of the incorporation measures. As a measure of educational achievement of the second generation, we use years of schooling completed. ${ }^{8}$

\section{Analysis and Estimation}

We chose a structural modeling approach as this gives us two advantages over a standard regression: first, it allows us to create a single variable to represent the concept of parental integration and simultaneously estimate the measurement of this variable and the regression equations we are interested in; second, the structural model allows us to trace the paths of independent variables, as they affect the transnational engagement of the second generation both directly and indirectly. For example, parental incorporation may yield a direct effect on children's cross-border activity - by embedding children more into the host society; however, integration may also exercise indi-

\footnotetext{
${ }^{7}$ In more than half of the Asian families, English was either exclusively or predominantly spoken at home. In contrast, only one-third of the Mexican respondents grew up in households where English was dominant by this measure. And while 55\% of the Mexican respondents grew up with Spanish as the dominant language, in only $37 \%$ of the Asian families was the parental home country language dominant.

${ }^{8}$ Using a categorical variable that indicates the level of degree received gives substantively the same results.
} 
rect effects via its impact on parental involvement in cross-border activity or via such second-generation resources that might influence cross-border ties, such as education.

The measurement model for the latent variable $\eta$ (parental integration) can be written as follows:

$$
Y=\tau+\Lambda \eta+\varepsilon,
$$

where $Y$ represents our vector of indicators of the latent variable, $\tau$ are the item thresholds, and $\Lambda$ is a matrix of factor loadings of the latent knowledge variable $\eta$. We also use multiple group structural equation analysis. Multiple group analysis estimates the structural equation model separately for each group (i.e., respondents with parents from Mexico vs. respondents with parents from Asian countries), but it allows us to constrain certain coefficients to be equal across groups and also to compare the groups by testing differences in coefficients across them. For these comparisons to be valid, the latent variable has to fulfill what is called "metric invariance," implying that differences in the observed items are meaningfully reflected in the underlying construct (Steenkamp and Baumgartner 1998). Since the observed variables that identify our latent construct are ordered categorically, for this condition to be fulfilled, the factor loadings $\Lambda$ and intercept parameters $\tau$ have to be the same across groups (Millsap and Yun-Tein 2004). We tested these assumptions and found that for the variable parents legal status, the cases we grouped under the rubric Asian have different intercepts than the other two groups. However, since the loadings and intercepts on the other two variables can be considered equal, our model fulfills partial scalar invariance, which is sufficient to allow for meaningful comparison across groups (Steenkamp and Baumgartner 1998, p. 81). Furthermore, we estimated our full model in both variants: once freeing these intercept variables for the Asian group and once constraining them to be equal across groups, the estimates for our parameters of interest are virtually identical in both cases and our substantive conclusions are the same.

\section{RESULTS}

\section{Descriptive Results}

Table 1 presents summary statistics for our five dependent variables.

Frequency of visits home since an adult. - The survey provides the number of times respondents have visited their parent's home country since adulthood. In order to take into account the varying ages of our respondents, we divided the number of visits by the years since the respondent turned age 18 . We then recoded the variable into seven categories: no visits, visits once every 10 years or less, once every 5 years, once every 3 years, ev- 
TABLE 1

Summary Statistics for the Five Types of Cross-Country Activities and Attachments Analyzed in Our Model

\begin{tabular}{|c|c|c|c|}
\hline & $\begin{array}{c}\text { Full Sample } \\
\text { Weighted } \\
(N=1,570)\end{array}$ & $\begin{array}{c}\text { Mexico } \\
(N=552)\end{array}$ & $\begin{array}{c}\text { Asian } \\
\text { Countries } \\
(N=721) \\
\end{array}$ \\
\hline \multicolumn{4}{|l|}{$\begin{array}{l}\text { Frequency of visits to parents' home country since } \\
\text { adult: }\end{array}$} \\
\hline Never. . . . . . . . . . . . . . . . & .30 & .27 & .40 \\
\hline \multicolumn{4}{|l|}{ Less than once every: } \\
\hline 10 years $\ldots \ldots \ldots \ldots \ldots \ldots$ & .08 & .07 & .17 \\
\hline 5 years $\ldots \ldots \ldots \ldots \ldots \ldots \ldots$ & .14 & .14 & .17 \\
\hline 3 years $\ldots \ldots \ldots \ldots \ldots \ldots$ & .13 & .14 & .12 \\
\hline 2 years $\ldots \ldots \ldots \ldots \ldots \ldots \ldots$ & .07 & .07 & .06 \\
\hline 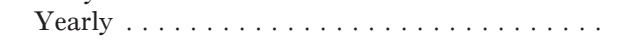 & .14 & .16 & .05 \\
\hline More than yearly $\ldots \ldots \ldots \ldots \ldots \ldots$ & .13 & .16 & .03 \\
\hline \multicolumn{4}{|l|}{ Sent remittances: } \\
\hline$\ldots \ldots \ldots \ldots \ldots$ & .61 & .59 & .72 \\
\hline Once or twice $\ldots \ldots \ldots \ldots \ldots \ldots \ldots$ & .10 & .10 & .11 \\
\hline Yearly $\ldots \ldots \ldots \ldots \ldots \ldots \ldots$ & .09 & .09 & .08 \\
\hline Several times a year $\ldots \ldots \ldots \ldots \ldots$ & .15 & .16 & .06 \\
\hline Monthly . . . . . . . . . . . . . . . . & .06 & .06 & .02 \\
\hline \multicolumn{4}{|l|}{$\begin{array}{l}\text { Member in organization related to parents' home } \\
\text { country: }\end{array}$} \\
\hline 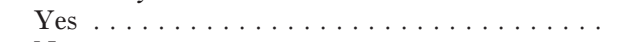 & .05 & .04 & .09 \\
\hline No ..................... & .95 & .96 & .91 \\
\hline \multicolumn{4}{|l|}{ Interested in the politics of parents' home country: } \\
\hline Strongly disagree. . . . . . . . . . . . . . . & .17 & .17 & .16 \\
\hline Disagree . . . . . . . . . . . . . . . & .23 & .22 & .26 \\
\hline Agree . . . . . . . . . . . . . . . & .43 & .42 & .48 \\
\hline Strongly agree $\ldots \ldots \ldots \ldots \ldots \ldots$ & .17 & .18 & .10 \\
\hline \multicolumn{4}{|l|}{ Which country feels most like home: } \\
\hline Parents' country of origin . . . . . . . . . & .06 & .06 & .04 \\
\hline United States and parents' country . . . . . . . & .03 & .04 & .01 \\
\hline United States only. . . . . . . . . . . . . & .91 & .90 & .95 \\
\hline
\end{tabular}

ery 2 years, yearly, and more often. Not surprisingly, visiting is most frequent among the Mexican second generation, where $73 \%$ visited their parents' home country at least once as an adult. Nonetheless, a majority of Asian respondents (60\%) also visited their parents' home country at least once. Similarly, very frequent visiting is more frequent among Mexicans, with about $30 \%$ visiting yearly or more often, while only $8 \%$ of Asian respondents do so.

Remitting.- The survey asked all 1.5- and second-generation respondents whether and how often they had sent money to anyone in their parents' home country. We recoded the information into an ordinal variable with five levels: those who never remitted, those who remitted only once or twice so far, those who remit every year, those who remit several times a 
year, and those who remit monthly or more often. The majority of respondents from each group never remitted, with Asians being even more likely to never have remitted. Of the Latino second generation, about one-third stated that they remitted yearly or more often, but not quite one-fifth of Asian respondents did so.

Interest in parents' home-country politics.-Respondents were asked whether they were interested in their parents' home country's politics. Here response patterns were fairly similar across groups, though Asian respondents seem to have somewhat lower interest on average. On a four-point scale, from strongly disagree to strongly agree, about $60 \%$ in each group either agree or strongly agree, while roughly $40 \%$ either disagree or disagree strongly.

Participation in organizations associated with parents' country of birth.-The survey asked whether respondents participated in any kind of organization associated with their own or their parents' country of birth in the last 12 months. Here Asian respondents were more active, with $9 \%$ indicating yes, while only $4 \%$ of the Mexican respondents did so. Unfortunately, the data do not give detailed information about the exact type of organizations the respondent participated in nor the intensity of participation.

Does parents' home country also feel like home.-Respondents were asked to list which country feels most like home, the United States or their parents' home country, or in the case of the 1.5 generation, their own country of birth. Multiple answers were allowed. We coded the responses into three categories: the United States only (mentioned by about $90 \%$ in the weighted sample), both the United States and the parents' home country, and a country other than the United States.

Just as parents pick and choose among cross-border activities, secondgeneration cross-border engagement is selective. Most respondents maintain at least one connection, but few keep up connections of all types. If we look at a simple sum scale of cross-border engagement, ${ }^{9}$ we see that less than $10 \%$ are not connected to the parental home country at all. However, less then $1 \%$ are connected in all five ways, and only $5 \%$ are connected in four of the five dimensions.

The loose, selective nature of these cross-border connections is reflected also by the modest correlations between the five types of border attachments we examine, as shown in table 2. Correlations range in the moderate to low level. Two pairs of activities show moderate correlations: political interest and membership in organizations, neither of which involves direct contact with the parental home country like visiting and remitting. Finally,

\footnotetext{
${ }^{9}$ This scale simply adds up dummy variables for engagement in the five activities. For the variables visiting and remitting, we code 1 all respondents who had ever done so. For the variable political interest, all respondents who answer agree or strongly agree are coded 1 .
} 
TABLE 2

Polychoric Correlations between Cross-Border Activities FOR THE Weighted SAMPLE

\begin{tabular}{|c|c|c|c|c|}
\hline & Visits & Remitting & $\begin{array}{l}\text { Feeling at } \\
\text { Home }\end{array}$ & $\begin{array}{c}\text { Interest in } \\
\text { Politics }\end{array}$ \\
\hline Remitting. . & .23 & & & \\
\hline Feeling at home $\ldots \ldots \ldots$ & .20 & .36 & & \\
\hline Interest in politics. . . . . . & .07 & .10 & .24 & \\
\hline $\begin{array}{c}\text { Membership in home country } \\
\text { organizations . . . . . . . }\end{array}$ & .09 & .10 & .02 & .19. \\
\hline
\end{tabular}

emotional attachment (feeling at home) is correlated with three of the other activities: remitting, visiting, and interest in politics.

\section{Structural Model}

Model summary and comparing coefficients across activities.-We first examine the results of our model to look at which variables affect specific types of cross-border ties in the second generation. In this initial presentation, we focus uniquely on direct effects. To provide a concise overview of the pattern, figure 2 displays the $Z$-statistics of the coefficients for the direct effects of parents' characteristics and second-generation education on the five types of cross-border ties in the second generation; full results are displayed in table 3 .

Looking at column 1 of table 3, we see that return to the home country during childhood yields significant effects on adult activities. However, those effects vary across outcomes, yielding a borderline significant effect on remitting, but additional and strong effects on the likelihood of feeling at home in the country of origin $(Z$-score $\sim 4)$ and the frequency of visits of second-generation adults, and significant, if slightly weaker, effects on membership in organizations. By contrast, parental remitting yields a significant and sizable effect $(Z$-score $\sim 4.5$ ) on second-generation remitting and borderline significant effects on membership in organizations and interest in parental home country politics. The coefficients for the other two dependent variables fail to reach statistical significance. Although home country language yields no single impact quite as great as the impact of parental remitting on child's remitting, it nonetheless has strong positive effects on secondgeneration remitting and the place where respondents feel at home, as well as the frequency of visits. Looking at columns 5 and 6 of table 3, we can see that our measures of parental integration and of educational achievement in the second generation only yield significant effects on the probability of second-generation membership in a homeland-oriented organization; coefficients for visiting are also suggestive but not statistically significant at 


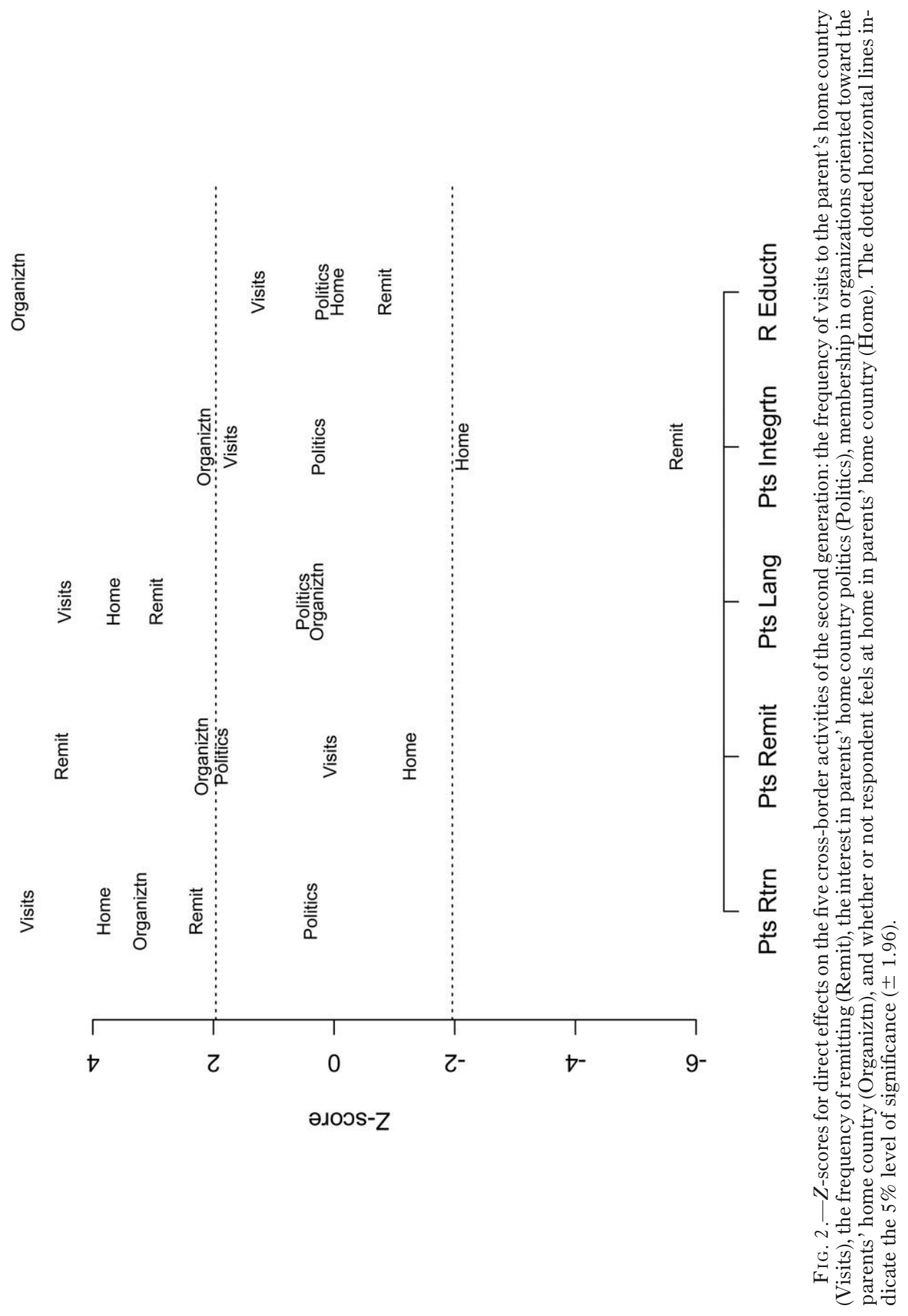


TABLE 3

Summary of Structural Equation Models: Direct Effects and Measurement Model

\begin{tabular}{|c|c|c|c|c|c|c|}
\hline & \multirow{2}{*}{\multicolumn{2}{|c|}{ Full Data Weighted }} & \multicolumn{4}{|c|}{ Multiple Group Model } \\
\hline & & & \multicolumn{2}{|c|}{ Mexico } & \multicolumn{2}{|c|}{ Asian Countries } \\
\hline & $\begin{array}{l}\text { Coefficient } \\
\text { (1) }\end{array}$ & $\begin{array}{c}Z \\
(2)\end{array}$ & $\begin{array}{l}\text { Coefficient } \\
\text { (3) }\end{array}$ & $\begin{array}{c}Z \\
(4)\end{array}$ & $\begin{array}{l}\text { Coefficient } \\
\text { (5) }\end{array}$ & $\begin{array}{c}Z \\
(6)\end{array}$ \\
\hline \multicolumn{7}{|l|}{ Direct effects: } \\
\hline \multicolumn{7}{|l|}{$\begin{array}{l}\text { Parents and respondent } \\
\text { return on } \ldots \ldots \ldots \ldots\end{array}$} \\
\hline Frequency of visiting . . . . & .32 & $5.09 * *$ & .34 & $4.20 * *$ & .26 & $3.22 * *$ \\
\hline Homeland organizations. . . & .32 & $3.19 * *$ & .40 & $3.54 * *$ & .03 & .23 \\
\hline Remitting. . . . . . . . . . & .15 & $2.29 *$ & .15 & $2.06 *$ & .10 & 1.21 \\
\hline Interest in politics $\ldots \ldots \ldots$ & .02 & .39 & .03 & .36 & .03 & .35 \\
\hline Feeling at home. . . . . . . . . & .32 & $3.82 * *$ & .34 & $3.49 * *$ & .19 & 1.34 \\
\hline \multicolumn{7}{|l|}{$\begin{array}{l}\text { Presence of language at } \\
\text { home on } \ldots \ldots \ldots \ldots \ldots\end{array}$} \\
\hline Frequency of visiting . . . . & .19 & $4.47 * *$ & .18 & $3.07 * *$ & .18 & $3.72 * *$ \\
\hline Homeland organizations. . . & .02 & .30 & .07 & .67 & .00 & .04 \\
\hline Remitting. . . . . . . . . . & .12 & $2.95 * *$ & .14 & $2.73 * *$ & .06 & 1.15 \\
\hline Interest in politics $\ldots \ldots \ldots$ & .02 & .48 & -.01 & -.19 & .08 & $1.70^{+}$ \\
\hline Feeling at home. . . . . . . . . & .24 & $3.66 * *$ & .31 & $3.17 * *$ & -.10 & -1.30 \\
\hline \multicolumn{7}{|l|}{ Parental remitting on ....... } \\
\hline Frequency of visiting . . . . . & .00 & .07 & .02 & .27 & -.08 & -1.48 \\
\hline Homeland organizations. . . & .23 & $2.17 *$ & .17 & 1.20 & .44 & $5.05 * *$ \\
\hline Remitting. . . . . . . . . . & .22 & $4.52 * *$ & .17 & $2.81 * *$ & .37 & $6.81 * *$ \\
\hline Interest in politics $\ldots \ldots \ldots$ & .10 & $1.87^{+}$ & .11 & 1.52 & .10 & $1.83^{+}$ \\
\hline Feeling at home. . . . . . . . & -.10 & -1.25 & -.16 & -1.61 & .00 & .02 \\
\hline \multicolumn{7}{|l|}{$\begin{array}{l}\text { Educational achievement } \\
\text { on } \ldots \ldots \ldots \ldots \ldots \ldots\end{array}$} \\
\hline \multicolumn{7}{|l|}{ Homeland } \\
\hline organizations........ & .11 & $5.21 * *$ & .13 & $3.15 * *$ & .04 & 1.08 \\
\hline Remitting. . . . . . . . . . & -.01 & -.84 & .00 & -.13 & -.08 & $-3.21 * *$ \\
\hline Interest in politics $\ldots \ldots \ldots$ & .00 & .16 & .00 & .08 & .02 & .96 \\
\hline Feeling at home. . . . . . . . & .00 & .05 & .00 & -.11 & -.03 & -.91 \\
\hline \multicolumn{7}{|l|}{ Parental assimilation on ..... } \\
\hline Frequency of visiting . . . . . & .10 & $1.72^{+}$ & .13 & $1.87^{+}$ & -.02 & -.21 \\
\hline Homeland organizations... & .19 & $2.13^{*}$ & .29 & $2.42 *$ & -.01 & -.10 \\
\hline Remitting. . . . . . . . . . & -.32 & $-5.67 * *$ & -.34 & $-5.29 * *$ & -.16 & $-1.95^{+}$ \\
\hline Interest in politics . . . . . . & .02 & .26 & .02 & .22 & .00 & -.02 \\
\hline Feeling at home. . . . . . . & -.20 & $-2.12 *$ & -.16 & -1.47 & -.53 & $-3.81 * *$ \\
\hline \multicolumn{7}{|l|}{$\begin{array}{l}\text { Parental assimilation on ..... } \\
\quad \text { Parents and respondent }\end{array}$} \\
\hline return . . . . . . . . . & -.11 & -1.61 & -.11 & -1.39 & .10 & 1.04 \\
\hline Parental remitting. . . . . . . . & .00 & -.04 & -.03 & -.48 & .17 & $2.47 *$ \\
\hline $\begin{array}{l}\text { Presence of language. ...... } \\
\text { Educational }\end{array}$ & -.49 & $-13.45 * *$ & -.45 & $-9.59 * *$ & -.67 & $-14.14 * *$ \\
\hline achievement $\ldots \ldots \ldots$ & 1.08 & $11.68 * *$ & 1.01 & $8.88 * *$ & .00 & .01 \\
\hline \multicolumn{7}{|l|}{$\begin{array}{l}\text { Measurement model for } \\
\text { parental assimilation: }\end{array}$} \\
\hline Legal status. . . . . . . . . . & .72 & 24.88 & .72 & 19.99 & .72 & 19.99 \\
\hline English proficiency . . . . . . . & .87 & 32.84 & .91 & 28.16 & .91 & 28.16 \\
\hline \multicolumn{7}{|l|}{ Any education in the } \\
\hline United States. . . . . . . . . & .71 & 21.39 & .64 & 17.01 & .64 & 17.01 \\
\hline CFI $\ldots \ldots \ldots \ldots \ldots \ldots$ & \multicolumn{2}{|c|}{.95} & \multicolumn{4}{|c|}{.93} \\
\hline RMSEA . . . . . . . . . & \multicolumn{2}{|c|}{.05} & \multicolumn{4}{|c|}{.07} \\
\hline
\end{tabular}

This content downloaded from 132.206.197.161 on July 13, 2016 08:16:11 AM

All use subject to University of Chicago Press Terms and Conditions (http://www.journals.uchicago.edu/t-and-c). 
conventional levels. Finally, parental integration yields a significant negative effect on remitting in the second generation $(Z$-score $\sim-5.5)$ and a somewhat more tenuous negative effect on the probability of feeling at home $(Z$-score $\sim-2) .{ }^{10}$

Stepping back and looking at the pattern overall, we can see four main relationships:

1. Home country effects: When adults, those respondents who accompanied a parent on an extended homeland visit during childhood were more likely to visit that place or do so more frequently, were more likely to feel at home there, were more likely to belong to a homeland-oriented organization, and were more likely to remit.

2. Remittance effects: Parental remitting, an activity most closely corresponding to what Faist labeled "transnational kinship circles," has a substantial effect on remitting in the second generation. Controlling for other variables, parental remitting has no effect on second-generation emotional connection to the parental home country and visits. It has a marginally significant effect on political interest and membership in organizations.

3. Language use effects: Mother tongue use in the parental household during childhood has a positive effect on outcomes-most notably, visiting and feeling at home in the parents' country of origin. Net of other factors, however, the presence of mother tongue during childhood does not increase political interest or participation in organizations, activities that are located in the United States and likely do not depend on proficiency in the parental language.

4. Integration effects: Respondents possessing more education and whose parents' were more familiar with and integrated into American society were more likely to be active in organizations concerned with their parent's home country but were less likely to feel at home there or to remit.

Differences between regions of origin.-Table 3 shows the full results of the models we estimated. The first model reflects the weighted sample of respondents from all origins. In the multiple group analysis, we allow the effects of parental characteristics on second-generation cross-border ties to vary while holding the measurement model of parental integration constant across groups.

\footnotetext{
${ }^{10}$ In a robustness test, we estimated this model omitting all respondents that came to the United States after their third birthday. All results we reported above are substantively the same, except for the negative effect of parental integration on feeling at home in the parents' home country; this effect disappears.
} 
While there are several instances where effects vary, not all differences are substantively meaningful. For example, looking at the effect of parental remitting on second-generation interest in politics, we see a significant effect $(P<.1)$ in the case of Asian respondents but not with those from Mexico. In this case, the coefficient is of similar magnitude in both groups but does fall just a bit short of the significance level in the case of the Mexican-origin respondents. In other relationships, for example, the effect of parental remitting on remitting in the second generation, there are differences in magnitude, yet qualitatively the relationships are the same across groups. Nevertheless, there are several differences worth noting.

Returning to the home country in childhood does not seem to increase connectedness among respondents with Asian parents. It does not increase the likelihood of joining organizations oriented toward the parental homeland, remitting, or having emotional attachments to the parents' native country. This finding is consistent with previous research that suggests that for the children of Chinese migrants visits to the home country are often fraught, underscoring the convergence of social and territorial boundaries rather than fostering a sense of cross-border connectivity (Louie 2006). Similarly, the presence of the home country language in the home does not increase emotional attachments in the Asian American second generation as it does among those with Mexican-born parents. However, there is a slight increase in interest in parental home country politics.

Remitting is a more central cross-border activity in Asian migrant families. The transmission of remitting across generations is more significant in Asian families as compared to those with Mexican origin. Also, parental remitting is associated with increases in political interest as well as membership in organizations.

Parental integration is consistently negatively associated with secondgeneration remitting and emotional attachment to the parental home country; however, we only find a significant direct effect on emotional attachment among Asian-origin respondents. As we show in the next section, the total effect is of similar magnitude in both groups.

At the same time, higher human capital is positively associated with frequency of visits to the parental home country, a finding consistent with hypothesis 3, which states that engagement in cross-border activities such as membership in organizations and international travel will be positively affected by educational achievement and the increased resources that are likely associated with parental integration into the host society. Among the Mexican-origin respondents, the higher resources and human capital that come with parental integration and as indicated by respondents' educational achievement translate into higher likelihood of joining organizations and frequency of visiting, while among Asian respondents, parental integration has consistently negative effects on cross-border activity. 
Direct and indirect effects. - The previous sections discussed the direct effects of parental characteristics on second-generation cross-border involvement. As is typical in multiple regression analysis, each effect is to be interpreted ceteris paribis. However, as laid out in our model, parental integration may also be associated with changes in parental cross-border activities or increases in educational achievement in the second generation. These effects are summarized in the second part of table 3. It is through these pathways that parental integration can yield indirect effects on secondgeneration transnational engagement. For example, since there is virtually no association between parental integration and the probability that respondents returned as children together with their parents, we expect to see no indirect effects through this pathway. In contrast, the presence of home country language seems negatively affected by higher levels of parental integration and thus presents a potential pathway for indirect effects. Comparing across groups, we again see some differences. In Mexican families, greater incorporation is associated with a significant increase in secondgeneration educational achievement, while in families with Asian origins, there is an increased probability of remitting. These differences will also affect the indirect effects in both groups: increased educational achievement of the second generation is a possible pathway for effects of higher parental integration among Mexican-origin respondents, while increased parental remitting associated with better integrated parents may translate into higher second-generation cross-border engagement in the case of Asianorigin families.

Table 4 summarizes a decomposition of these effects of parental integration on the five aspects of second-generation transnationalism we examined. For each variable, the first row presents the total effect, which is the sum of the direct effects presented in table 3 as well as all indirect effects. The following row presents the sum of all indirect effects, and the next four rows break out the effects for each pathway. ${ }^{11}$

Looking at the first set of results, that on the frequency of visiting, we see that overall the effect of parental integration on the frequency of visiting is zero, whereas the direct effect (table 3 ) is positive. We see that in the sample overall, as in the separate analyses, parental integration has a negative effect on visiting in the second generation by decreasing the presence of the home country language at home. As we expected, parental integration, on the one hand, will mean an increase in resources and human capital for the

\footnotetext{
${ }^{11}$ The coefficients for the indirect effects can also be calculated directly from table 2 by multiplying the coefficients along each pathway. For example, the indirect effect of parental integration on visiting via the presence of parental home country language at home $(-0.09)$ is the product of the effect of integration on the presence of language $(-0.49)$ and the effect of language presence on visiting (0.19). However, these calculations do not provide the tests of statistical significance presented in table 4 .
} 
TABLE 4

Summary of Structural Equation Model (Continued): Indirect Effects of Parental Assimilation on Second-Generation Transnational Activities

\begin{tabular}{|c|c|c|c|c|c|c|}
\hline & \multirow{2}{*}{\multicolumn{2}{|c|}{ All Group Weighted }} & \multicolumn{4}{|c|}{ Multiple Group Model } \\
\hline & & & \multicolumn{2}{|c|}{ Mexico } & \multicolumn{2}{|c|}{ Asian Countries } \\
\hline & $\begin{array}{c}\text { Coefficient } \\
\text { (1) }\end{array}$ & $\begin{array}{c}Z \\
(2)\end{array}$ & $\begin{array}{c}\text { Coefficient } \\
\text { (3) }\end{array}$ & $\begin{array}{c}Z \\
(4)\end{array}$ & $\begin{array}{c}\text { Coefficient } \\
(5)\end{array}$ & $\begin{array}{c}Z \\
(6)\end{array}$ \\
\hline \multicolumn{7}{|l|}{ Frequency of visiting: } \\
\hline Total .......... & .00 & -.05 & .07 & 1.26 & -.13 & $-2.36 *$ \\
\hline Total indirect . . . . & -.11 & $-2.77 * *$ & -.07 & -1.43 & -.11 & $-2.52 *$ \\
\hline $\begin{array}{l}\text { Via respondent } \\
\text { education } \ldots . . .\end{array}$ & .02 & 1.27 & .05 & $2.60 * *$ & .00 & .01 \\
\hline $\begin{array}{l}\text { Return to home } \\
\text { country ....... }\end{array}$ & -.03 & -1.53 & -.04 & -1.32 & .03 & .94 \\
\hline $\begin{array}{l}\text { Parents remitting. . } \\
\text { Language at }\end{array}$ & .00 & -.04 & .00 & -.24 & -.01 & -1.27 \\
\hline $\begin{array}{l}\text { home. . . . . . . } \\
\text { Membership in } \\
\text { organizations: }\end{array}$ & -.09 & $-4.24 * *$ & -.08 & $-2.88 * *$ & -.12 & $-3.87 * *$ \\
\hline Total . . . . . . . . & .27 & $4.08 * *$ & .34 & $3.76 * *$ & .06 & .67 \\
\hline Total indirect . . . . & .07 & 1.42 & .05 & .62 & .07 & 1.18 \\
\hline $\begin{array}{l}\text { Via respondent } \\
\text { education } \ldots . . .\end{array}$ & .12 & $4.69 * *$ & .13 & $2.97 * *$ & .00 & .01 \\
\hline Return to home & & & & & & \\
\hline country . . . . . & -.03 & -1.48 & -.04 & -1.31 & .00 & .22 \\
\hline $\begin{array}{l}\text { Parents remitting. . } \\
\text { Language at }\end{array}$ & .00 & -.04 & -.01 & -.44 & .07 & $2.33 *$ \\
\hline home. . . . . . . & -.01 & -.30 & -.03 & -.67 & .00 & -.04 \\
\hline \multicolumn{7}{|l|}{ Remitting: } \\
\hline Total . . & -.41 & $-10.12 * *$ & -.43 & $-9.11 * *$ & -.14 & $-2.22 *$ \\
\hline Total indirect . . . . & -.09 & $-2.74 * *$ & -.09 & $-2.44 *$ & .03 & .56 \\
\hline $\begin{array}{l}\text { Via respondent } \\
\text { education } \ldots \ldots\end{array}$ & -.01 & -.84 & .00 & -.13 & .00 & -.01 \\
\hline Return to home & & & & & & \\
\hline country ........ & -.02 & -1.34 & -.02 & -1.19 & .01 & .73 \\
\hline $\begin{array}{l}\text { Parents remitting. . } \\
\text { Language at }\end{array}$ & .00 & -.04 & -.01 & -.48 & .06 & $2.36^{*}$ \\
\hline home. . . . . . . . & -.06 & $-2.96 * *$ & -.06 & $-2.72 * *$ & -.04 & -1.16 \\
\hline \multicolumn{7}{|l|}{ Interest in politics: } \\
\hline Total . . . . . . . & .01 & .12 & .02 & .30 & -.03 & -.60 \\
\hline Total indirect . . . . & -.01 & -.35 & .00 & .01 & -.03 & -.98 \\
\hline $\begin{array}{l}\text { Via respondent } \\
\text { education } \ldots . . .\end{array}$ & .00 & .16 & .00 & .08 & .00 & .01 \\
\hline Return to home & & & & & & \\
\hline country . . . . . & .00 & -.38 & .00 & -.34 & .00 & .32 \\
\hline Parents remitting. . . & .00 & -.04 & .00 & -.45 & .02 & 1.51 \\
\hline $\begin{array}{l}\text { Language at } \\
\text { home. . . . . . . }\end{array}$ & -.01 & -.48 & .01 & .19 & -.05 & $-1.73^{+}$ \\
\hline Feeling at home: & & & & & & \\
\hline Total . . . . . . . & -.35 & $-5.12 * *$ & -.34 & $-4.18 * *$ & -.44 & $-4.22 * *$ \\
\hline Total indirect . . . & -.15 & $-2.85 * *$ & -.17 & $-2.63 * *$ & .09 & 1.36 \\
\hline $\begin{array}{l}\text { Via respondent } \\
\text { education } \ldots . . .\end{array}$ & .00 & .05 & .00 & -.11 & .00 & -.01 \\
\hline
\end{tabular}


TABLE 4 (Continued)

\begin{tabular}{|c|c|c|c|c|c|c|}
\hline & \multirow{2}{*}{\multicolumn{2}{|c|}{ All Group Weighted }} & \multicolumn{4}{|c|}{ Multiple Group Model } \\
\hline & & & \multicolumn{2}{|c|}{ Mexico } & \multicolumn{2}{|c|}{ Asian Countries } \\
\hline & $\begin{array}{c}\text { Coefficient } \\
\text { (1) }\end{array}$ & $\begin{array}{c}Z \\
(2)\end{array}$ & $\begin{array}{c}\text { Coefficient } \\
\text { (3) }\end{array}$ & $\begin{array}{c}Z \\
(4)\end{array}$ & $\begin{array}{c}\text { Coefficient } \\
\text { (5) }\end{array}$ & $\begin{array}{c}Z \\
(6)\end{array}$ \\
\hline $\begin{array}{l}\text { Return to home } \\
\text { country ....... }\end{array}$ & -.03 & -1.49 & -.04 & -1.30 & .02 & .77 \\
\hline Parents remitting. . . & .00 & .04 & .01 & .46 & .00 & .02 \\
\hline $\begin{array}{l}\text { Language at } \\
\text { home. . . . . . . }\end{array}$ & -.12 & $-3.73^{* *}$ & -.14 & $-3.16 * *$ & .07 & 1.26 \\
\hline
\end{tabular}

second generation, which makes travel abroad more likely; on the other hand, parental integration also entails a decrease in the presence of home country language, a key competency for trips to the old country as well as a vehicle that transmits emotional attachments. While this story plays out in all three samples, the total effect is slightly different in each case. In the Asian subsample, there was a nonsignificant direct effect of parental integration, which then, together with a negative indirect effect, yields a negative total effect. In the case of Mexican respondents, a positive direct effect is offset by a negative indirect effect, yielding a total effect that is not significantly different from zero.

Among the Mexican respondents, the increase in second-generation human capital associated with parental integration also contributes to higher membership in homeland-oriented organizations, while parental remitting presents a small but statistically significant pathway in the case of Asian families. The effect on remitting in the second generation presents a similar pattern; again, for the Asian respondents, parental remitting is a small but significant pathway, while for Mexican families, language is a pathway for the indirect effect of parental integration. Finally, though the overall effect of parental integration on feeling at home is negative and of the same magnitude in both groups, in the Mexican-origin subsample, the associated decline in the parental language spoken at home is a pathway for this effect, but this is not so in the Asian-origin subsample.

\section{DISCUSSION}

Notwithstanding the high level of ongoing international migration to the United States, the relative importance of the second and third generations originating in the Americas and Asia will certainly rise. As suggested by one recent projection (Suro and Passel 2003), by 2050 the foreign born are likely to make up only one-quarter of the Hispanic population. Whether the chil- 
dren of migrants maintain homeland ties will therefore be of critical importance to the future of the cross-border connections that the first generation has put in place.

But how do the U.S.-born children of immigrants, who have typically had only limited direct exposure to their parents' home country, develop cross-border attachments? Proponents of the transnational paradigm contend that the source of second-generation home country ties is to be found in the transnational social fields in which these immigrant offspring grow up, which exposes them to an environment characterized by a back and forth movement of people, ideas, goods, and practices. However, for the second generation, the experience of this environment is filtered through the parental household. Consequently, parents' own engagement with the homeland and their retention of homeland practices are likely to exercise much influence over the degree to which their children will form crossborder social ties, attachments, and obligations in adulthood.

As we have shown, parental involvement matters, supporting our first, most general hypothesis. Respondents whose parents were actively involved in cross-border activities or who grew up in households where the parent's home country language was present were more likely to have cross-border ties themselves once they reach adulthood. Four of our five indicators of second-generation transnationalism were positively affected by some measure of parental cross-border involvement. However, we find no effects on interest in the politics of the parents' home country, an exception possibly due to the data set's lack of a measure of parental political interest (thus precluding an assessment of the impact of political socialization) or reflecting the importance of extra-familial influences on this dimension of second-generation transnationalism.

By contrast, parental integration in the host society yields more variable effects. The more embedded are the parents in the United States, the less likely are their children to feel emotionally attached to the parents' home and the less likely they are to send remittances. However, for the Mexican second generation, parental integration has positive effects on secondgeneration educational profiles, which in turn spurs their participation in homeland organizations and, other variables held constant, increases the frequency of visiting. Thus, as we hypothesized (hypothesis 3), while generally distancing the second generation from the home country, for activities that are reflective of higher human capital, such as political and social engagement and travel, parental integration into the host society may have positive effects. Just as the neoclassic assimilation theory outlined by Alba and Nee predicts, better incorporation of a family into host country institutions and society means more opportunities for social mobility. This mobility in turn can provide resources that allow for greater cross-border connectivity. 
Most importantly, migrant parents directly impart skills to their children that enable them to maintain meaningful ties to the home country. Most critical is familiarity with the home country language. As our results show, the presence of the parental language during childhood translates into increased frequency of visiting in adulthood. That language also yields a greater connection to kinship circles is reflected in the higher likelihood of remitting. Language, of course, is the essence of communication: it is difficult to feel at home or to find a fundamental sense of kinship with homeland relatives or communities if the meanings of speech can no longer be taken for granted.

As the complexity of our results shows, rather than growing up in a coherently organized "transnational social field," the second generation gains cross-border connections via a set of distinct ties, each of which has its own "mechanism of [cross-border] integration," to borrow a phrase from Thomas Faist (2000, p. 191). As posited in our fourth hypothesis, we find distinct transmission pathways. Parental remitting, an activity located in the domain of intimate cross-border family relations, has a clear positive effect on remitting in the second generation. But parental remitting is narrowly targeted to a very specific set of significant others abroad, as suggested by the discrepancy between the huge flows of worker remittances that migrants send to their families and the meager sums sent as "collective remittances" to be used for some homeland public good (Kapur and McHale 2005). Not surprisingly, then, parental remitting yields only limited effects on all of the other activities and attachments we examined. At the same time, extended home country visits during childhood yield significant positive effects on four of the five outcomes (emotional attachment to the parents' home country, frequency of visiting, remitting, and involvement in homeland-oriented organizations). This relationship likely reflects the ways in which visits during childhood reinforce the attachment that immigrant offspring feel not just to relatives but also to the larger place and broader set of people left behind.

Although it was not the focus of our inquiry, our results also shed light on the "how much" question: To what extent will cross-border ties persist over generations? That home country connections fall off from the first to the second generation is a matter of general scholarly consensus. Having examined the transmission process from first to second generations, we are now in a position to forecast likely shifts as the second generation is eventually replaced by the third. The overall fall-off in second-generation cross-border activity means that the third generation will have limited exposure to direct omeland engagements, at least as mediated through the parental household. Just as important, they are likely to be deprived of one of the most powerful factors affecting homeland engagement, namely, mother tongue use at 
home. As we have seen, the presence of the home country language in the home plays a central role for the transmission of home country ties. Since scholarship clearly demonstrates that English displaces the parents' native language in the day-to-day life of the second generation at a rapid rate (Rumbaut et al. 2006), this avenue of intergenerational transmission will largely be foreclosed.

In conclusion, we argue that progress in understanding the ways in which the cross-border activities of migrants are transmitted from one generation to another requires a disaggregated approach, separating out the different components undergirding homeland engagement according to the distinct social mechanisms that underpin them. While this article presents a first step in that direction, much work remains to be done as parental influence is only one avenue for the transmission of cross-border attachments and transnational engagements of the second generation. Systematic analysis of the effects of contexts outside the home, such as ethnic neighborhoods, schools, community organizations, or professional contacts, would be important complements to the analysis presented here. While we believe that our findings do capture the general dynamics of the transmission process and that the transmission of home country attachments seems to work in similar ways across families from different regions, our separate analysis by region of origin also indicates some cases where differences exist. However, our data allowed us only to compare two very broad regional groupings; further disaggregation by country of origin would surely yield additional insights.

APPENDIX

TABLE A1

Summary Statistics for Parental Characteristics and Second-Generation Educational Achievement

\begin{tabular}{|c|c|c|c|}
\hline & $\begin{array}{c}\text { Full Sample } \\
\text { Weighted } \\
(N=1,570)\end{array}$ & $\begin{array}{c}\text { Mexico } \\
(N=552)\end{array}$ & $\begin{array}{c}\text { Asian } \\
\text { Countries } \\
(N=721)\end{array}$ \\
\hline \multicolumn{4}{|l|}{ Parents' integration: } \\
\hline \multicolumn{4}{|l|}{ Legal status of parents: } \\
\hline None legal. . . . . . . . & .06 & .06 & .04 \\
\hline One has green card & .06 & .07 & .02 \\
\hline Both have green card. . . . . . . . & .16 & .18 & .04 \\
\hline One citizen $\ldots \ldots \ldots \ldots \ldots$ & .28 & .28 & .16 \\
\hline Both citizens . . . . . . . . & .45 & .40 & .75 \\
\hline \multicolumn{4}{|l|}{$\begin{array}{l}\text { Parents received education in the } \\
\text { United States: }\end{array}$} \\
\hline None. . . . . . . . . . . . . . . . & .78 & .80 & .73 \\
\hline One $\ldots \ldots \ldots \ldots \ldots \ldots$ & .16 & .15 & .19 \\
\hline Both . . . . . . . . . & .05 & .05 & .08 \\
\hline
\end{tabular}


American Journal of Sociology

TABLE A1 (Continued)

\begin{tabular}{|c|c|c|c|}
\hline & $\begin{array}{c}\text { Full Sample } \\
\text { Weighted } \\
(N=1,570)\end{array}$ & $\begin{array}{c}\text { Mexico } \\
(N=552)\end{array}$ & $\begin{array}{c}\text { Asian } \\
\text { Countries } \\
(N=721)\end{array}$ \\
\hline \multicolumn{4}{|l|}{ Parents' English ability: } \\
\hline None well . . . . . . . . . . & .24 & .26 & .18 \\
\hline One well. . & .31 & .31 & .23 \\
\hline$\ldots \ldots \ldots \ldots$ & .46 & .43 & .59 \\
\hline \multicolumn{4}{|l|}{$\begin{array}{l}\text { Parents' homeland-oriented } \\
\text { activities: }\end{array}$} \\
\hline \multicolumn{4}{|l|}{ Language spoken at home: } \\
\hline English only $\ldots \ldots \ldots \ldots \ldots$ & .09 & .07 & .22 \\
\hline Mostly English . . . . . . . . . . . & .24 & .24 & .30 \\
\hline \multicolumn{4}{|l|}{ English and home-country } \\
\hline language about equal . . . . . . . & .14 & .14 & .11 \\
\hline Mostly home country language. . . & .53 & .55 & .37 \\
\hline Parents remitted . . . . . . . . . . . & .65 & .64 & .65 \\
\hline \multicolumn{4}{|l|}{ Parents and respondent return to } \\
\hline home-country ............ & .11 & .12 & .07 \\
\hline \multicolumn{4}{|l|}{ Educational achievement of respondent: } \\
\hline 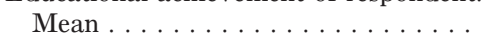 & 13.3 & 12.8 & 15.8 \\
\hline $\mathrm{SD} \ldots \ldots \ldots \ldots \ldots \ldots$ & 2.7 & 2.6 & 2.1 \\
\hline
\end{tabular}

\section{REFERENCES}

Alba, Richard. 1990. Ethnic Identity: The Transformation of White America. New Haven, Conn.: Yale University Press

Alba, Richard, and Victor Nee. 2003. Remaking the American Mainstream: Assimilation and Contemporary Immigration. Cambridge, Mass. Harvard University Press.

Anderson, Benedict. 2006. Imagined Communities: Reflections on the Origin and Spread of Nationalism. London: Verso.

Bandura, Albert. 1977. Social Learning Theory. Englewood Cliffs, N.J.: Prentice Hall.

- 1986. Social Foundations of Thought and Action: A Social Cognitive Theory. Englewood Cliffs, N.J.: Prentice-Hall.

. 2002. "Social Cognitive Theory in Cultural Context." Applied Psychology 51:269-90.

Banton, Michael. 2001. "National Integration in Britain and France." Journal of Ethnic and Migration Studies 27:151-68.

Bean, Frank, and Gillian Stevens. 2003. America's Newcomers and the Dynamics of Diversity. New York: Russell Sage Foundation.

Bean, Frank D., Mark A. Leach, Susan K. Brown, James D. Bachmeier, and John R. Hipp. 2011. "The Educational Legacy of Unauthorized Migration: Comparisons across U.S.-Immigrant Groups in How Parents' Status Affects Their Offspring." International Migration Review 45:348-85.

Bloemraad, Irene, and Christine Trost. 2008. "It's a Family Affair." American Behavioral Scientist 52:507-32.

Brubaker, Rogers, Margit Feischmidt, Jon Fox, and Linea Grancea. 2006. Nationalist Politics and Everyday Ethnicity in a Transylvanian Town. Princeton, N.J.: Princeton University Press. 
Espiritu, Yen Le. 2003. Home Bound: Filipino American Lives across Cultures, Communities, and Countries. Berkeley and Los Angeles: University of California Press.

Faist, Thomas. 2000. "Transnationalization in International Migration: Implications for the Study of Citizenship and Culture." Ethnic and Racial Studies 23: $189-222$.

Fasold, Ralph. 1984. The Sociolinguistics of Society. New York: Blackwell.

Fishman, Joshua. 1989. Language and Ethnicity in Minority Sociolinguistic Perspective. Cleveland: Multilingual Matters.

Fouron, Georges E., and Nina Glick-Schiller. 2002. "The Generation of Identity: Redefining the Second Generation within a Transnational Social Field.” Pp. 58-86 in The Changing Face of Home: The Transnational Lives of the Second Generation, edited by Peggy Levitt and Mary C. Waters. New York: Russell Sage Foundation.

Fraga, Luis R., John A. Garcia, Rodney Hero, Michael Jones-Correa, Valerie Martinez-Ebers, and Gary M. Segura. 2006. Latino National Survey (LNS). [Computer file]. ICPSR20862-v4. Ann Arbor, Mich.: Inter-university Consortium for Political and Social Research [distributor].

. 2010. Latino Lives in America: Making It Home. Philadelphia: Temple University Press.

Gellner, Ernest. 1983. Nations and Nationalism. Ithaca, N.Y.: Cornell University Press.

Giles, Howard, and Nikolas Coupland. 1991. Language: Contexts and Consequences. Milton Keynes: Open University Press.

Guarnizo, Luis E., Alejandro Portes, and William Haller. 2003. "Assimilation and Transnationalism: Determinants of Transnational Political Action among Contemporary Migrants.” American Journal of Sociologv 108:1211-48.

Haikkola, Lotta. 2011. "Making Connections: Second-Generation Children and the Transnational Field of Relations." Journal of Ethnic and Migration Studies 37: 1201-17.

Hess, Robert T., and Judith V. Torney-Purta. 1965. The Development of Basic Attitudes and Values toward Government and Citizenship during the Elementary School Years: Part I. Cooperative Research Project no. 1078, U.S. Office of Education. Chicago: University of Chicago.

Hyman, Herbert Hiram. 1959. Political Socialization: A Study in the Psychology of Political Behavior. Glencoe, Ill. Free Press.

Itzigsohn, Jose. 2009. Encountering American Faultines: Race, Class, and Dominican Incorporation in Providence. New York: Russell Sage Foundation.

Itsigsohn, Jose, Carlos Dore Cabral, Esther Hernandez Medina, and Obed Vazquez. 1999. "Mapping Dominican Transnationalism: Narrow and Broad Transnational Practices." Journal of Ethnic and Migration Studies 22:316-39.

Jennings, Michael Kent, and Richard G. Niemi. 1968. "The Transmission of Political Values from Parent to Child." American Political Science Review 61:169-84.

. 1974. The Political Character of Adolescence: The Influence of Families and Schools. Princeton, N.J. Princeton University Press.

Jennings, Kent, Laura Stokers, and Jake Bowers. 1999. Politics across Generations: Family Transmission Reexamined. Working paper no. 2001-15, University of California, Berkeley, Institute of Governmental Studies.

Jones-Correa, Michael. 2002. "The Study of Transnationalism among the Children of Immigrants: Where We Are and Where We Should Be Headed." Pp. 221-41 in The Changing Face of Home: The Transnational Lives of the Second Generation, edited by Peggy Levitt and Mary C. Waters. New York: Russell Sage Foundation. 
American Journal of Sociology

Kapur, Devesh, and John McHale. 2005. Give Us Your Best and Brightest: The Global Hunt for Talent and Its Impact on the Developing World. Washington, D.C.: Center for Global Development.

Kasinitz, Philip, John H. Mollenkopf, Mary C. Waters, and Jennifer Holdaway. 2008. Inheriting the City: The Children of Immigrants Come of Age. Cambridge, Mass.: Harvard University Press.

Kibria, Nazil. 2002. Becoming Asian American: Second-Generation Chinese and Korean American Identities. Baltimore, Md.: Johns Hopkins University Press.

Levitt, Peggy. 2001. The Transnational Villagers. Berkeley and Los Angeles: University of California Press.

Levitt, Peggy, and Nina Glick-Schiller. 2004. "Conceptualizing Simultaneity: A Transnational Social Field Perspective on Society,." International Migration Review 38:1002-39.

Levitt, Peggy, and Mary C. Waters. 2002. The Changing Face of Home: The Transnational Lives of the Second Generation. New York: Russell Sage Foundation.

Lopez, David, and Vanesa Estrada. 2007. "Language." Pp. 228-42 in New Americans: A Guide to Immigration since 1965, edited by Mary Waters and Reed Ueda. Cambridge, Mass.: Harvard University Press.

Louie, Vivian. 2006. "Second-Generation Pessimism and Optimism: How Chinese and Dominicans Understand Education and Mobility Tthrough Ethnic and Transnational Orientations." International Migration Review 40:537-72.

Lucassen, Leo. 2006. "Is Transnationalism Compatible with Assimilation? Examples from Western Europe since 1850." IMIS-Beitraege 29:15-35.

Mason, Jennifer, 2004. "Managing Kinship over Long Distances: The Significance of 'The Visit'." Social Policv and Societv 3:421-29.

Millsap, Roger, and Jenn Yun-Tein. 2004. "Assessing Factorial Invariance in Ordered-Categorical Measures." Multivariate Behavioral Research 39:479-515.

Morawska, Ewa. 2003. "Immigrant Transnationalism and Assimilation: A Variety of Combinations and the Analytic Strategy It Suggests." Pp. 133-76 in Toward Assimilation and Citizenship: Immigrants in Liberal Nation-States, edited by Christian Joppke. London: Palgrave Macmillan.

Niemi, Richard G., and Mary A. Hepburn. 1995. "The Rebirth of Political Socialization." Perspectives on Political Science 24:7-16.

Portes, Alejandro, Luis E. Guarnizo, and Patricia Landolt. 1999. "The Study of Transnationalism: Pitfalls and Promise of an Emergent Research Field." Ethnic and Racial Studies 22:217-37.

Portes, Alejandro, William J. Haller, and Luis E. Guarnizo. 2002. "Transnational Entrepreneurs: An Alternative Form of Immigrant Economic Adaptation." American Sociological Review 67:278-98.

Purkayastha, Bandana. 2005. Negotiating Ethnicity: Second-Generation South Asian Americans Traverse a Transnational World. Piscataway, N.J.: Rutgers University Press.

Rumbaut, Rubén G., Frank D. Bean, Leo R. Chávez, Jennifer Lee, Susan K. Brown, Louis DeSipio, and Min Zhou. 2004. Immigration and Intergenerational Mobility in Metropolitan Los Angeles (IIMMLA) [Computer File]. ICPSR22627-v1. Ann Arbor, Mich.: Inter-university Consortium for Political and Social Research [distributor].

Rumbaut, Ruben G., Douglas S. Massey, and Frank Bean. 2006. "Linguistic Life Expectancies: Immigrant Language Retention in Southern California." Population and Development Review 32:447-60.

Sapiro, Virginia 2004. "Not Your Parents' Political Socialization: Introduction for a New Generation." Anmual Review of Political Science 7:1-23.

Schuetz, Alfred. 1944. "The Stranger: An Essay in Social Psychology." American Journal of Sociologv 49:499-507. 
Smith, Robert C. 2006. Mexican New York: Transnational Lives of New Immigrants. Berkeley and Los Angeles: University of California Press.

Soehl, Thomas, and Waldinger, Roger D. 2010. "Making the Connection: Latino Immigrants and Their Cross-border Ties." Ethnic and Racial Studies 33: $1489-1510$.

Steenkamp, Jan-Benedict E. M., and Hans Baumgartner. 1998. "Assessing Measurement Invariance in Cross-National Consumer Research." Journal of Consumer Research 25:78-107.

Suro, Roberto, and Jeffrey S. Passel. 2003. "The Rise of the Second Generation: Changing Patterns in Hispanic Population Growth." Pew Hispanic Center, Washington, D.C.

Terriquez, Veronica. 2011. "Schools for Democracy Labor Union Participation and Latino Immigrant Parents' School-Based Civic Engagement.” American Sociological Review 76:581-601.

Verba, Sidney, Kay Lehan Schlozman, and Henry E. Brady. 1995. Voice and Equality: Civic Voluntarism in American Politics. Cambridge, Mass.: Harvard University Press.

Waldinger, Roger. 2008. "Between 'Here' and 'There': Immigrant Cross-Border Activities and Loyalties." International Migration Review 42:3-29.

Waldinger, Roger, Thomas Soehl, and Nelson Lim. 2012. "Emigrants and the Body Politic Left Behind." Journal of Ethnic and Migration Studies 38:711-36.

Wong, Janelle, and Vivian Tseng. 2008. "Political Socialization in Immigrant Families: Challenging Top-Down Parental Socialization Models." Journal of Ethnic and Migration Studies 34:151-68. 